\title{
Game Study on the Entity in Green Building Market in China
}

\author{
Yuping Bai \\ Xuzhou Institute of Technology \\ Xuzhou, Jiangsu, China 221000
}

\begin{abstract}
By studying the current situation of the green building market and analyzing the reasons for current situation, this paper uses the game theory to study the three entities of green building market: government, construction enterprises and consumers' benefit distribution in the promotion of green building, and explores the approach of further promoting the green building in China, to provide a reference for research on sustainable social development.
\end{abstract}

Keywords-green building; market entity; construction enterprise; consumer; game

\section{INTRODUCTION}

Ever since the state officially introduced documents and began to promote in 2006, China's green building has made some achievements. The national green building area and quantity are in rapid growth, by the end of 2015, there had been totally 3636 green building labeling programs in China, among which 1098 projects were newly increased in 2015 (data source: Public statistic data of green building labeling programs of the Ministry of Housing and Urban-Rural Development). However, as far as the distribution of development of green building in all the provinces in China is concerned, there are still many problems.

\section{ENTITY OF GREEN BUILDING MARKET AND THE MAIN FEATURES}

As part of the green economy, Green building is gradually attracting the attention of more and more people through the government's promote and market's operation. There are three main entities in China's green building market: construction enterprises, consumers and government. The green building has owned the functional value of energy saving and environmental protection in product quality. There is also incremental cost compared to ordinary buildings. In the early stage of the development of green building market which was imperfect, there was no perfect sharing mechanism of green cost and market benefit distribution mechanism. The green construction market's three main entities: the construction enterprises, consumers and the government all have their own interests, but the green market economy's behavior does not match with the direct interests of these entities, and there are also contradictions between the individual interests and social interests of enterprises, consumers and the government,

Fund Project: Science and Technology Project Plan of the Ministry of Housing and Urban-Rural Development (2010-R1-8), Science and Technology Project Plan of Jiangsu Province (201207200029). between the current interests and the long-term interests of the state, and between the local interests and the overall interests. All the entities want to get the greatest benefits with lowest cost, rather than take the initiative to sacrifice their own interests to pay for the incremental cost of green building. Thus the further development of green building is restricted.

\section{A. Construction Enterprises' Role and Interest Demand in the Green Building Market}

The construction enterprise is an important entity to form the green building, including various professional enterprises that participate in the formation of green building such as construction enterprises, architectural design enterprises, cost consulting firms, supervision companies. They are the most important economic organizations in the green building market, whose function is to provide green buildings to meet the needs of consumers in the framework of national policies according to the needs of the green building market. As a product producer, the purpose of construction enterprises is to obtain the greatest economic benefits with lowest production input, so as to achieve appreciation in enterprise's asset value. In the green building market, as the entity of production and marketing, enterprises undertake tasks such as research and development of green building related technology, production of green building and marketing of green building. While achieving their own economic pursuit, the construction enterprises improve the level of green building's production technology, save social resources and protect the ecological environment; and can also obtain government and consumer's recognition through the construction of green building, enhance corporate image, which helps to improve their own competitiveness in the long run, and can develop continuously and stably in the future.

Today, the green building is not yet popular, due to incomplete market system and low consumer acceptance of green building, the enterprises have to bear the incremental cost of green buildings, but the green benefits brought by it is shared by consumers and the whole society. Such external effect leads to high investment low income of enterprises, which makes it difficult for them to take the initiative to assume social responsibility, and thus can not play the due role of promoting in the green building market. 


\section{B. Consumers' Role and Interest Demand in the Green Building Market}

Consumers make an important part of the market. Today, with the booming development of real estate industry, consumers are not only leading the market demand, but are also the source to promote the rapid development of the market. The purpose of their participation in market activities is to maximize their own benefits and welfare through the purchase behavior of green building. Because of the incremental cost of green building, the consumers' purchase behavior must be carried out under the premise that they fully understand the advantages of green building and are willing to bear the incremental cost. As a result, the external cost of green costs will appear when consumers make purchasing decisions. Green buildings not only provide consumers with a more comfortable and environmentally friendly living environment, improve their living standards, but also, meanwhile, the existence of green buildings contributes to the sustainable development of the whole society and improvement of the global climate. So that it achieves the unity of consumer's personal interests and the social interests.

This consumer behavior is based on consumers' awareness of green building, and rational consumers prefer to maximize the personal or family utility with minimum monetary expenditure, rather than maximize the social welfare. Therefore, as a "rational broker", it's difficult for consumers to "sacrifice their own interests for the sake of others" in the purchase of green building.

\section{The Government's Role and Interest Demand in the Green Building Market}

The key to the promotion and implementation of green building lies in the government. As the guiding force and social manager in green building market, government's duty is to improve people's living standards through the implementation of administrative power. The development of green building is the specific performance of realizing environmental improvement, effective use of resources and sustained economic development. Therefore, in the development of green building, the government has the highest awareness of environmental protection and social responsibility. Its function is to integrate the relevant resources and environmental factors of the country into the economic development plan, to establish relevant systems adapted to the development of green building by formulating relevant policies and regulations and adopting financial and administrative means; and to supervise and guarantee the rapid development of green building. From the national level, the resource conservation and environmental improvement brought by green building help to improve the social welfare of the people, and also benefit the sustainable development of the whole society. Government has an inescapable responsibility for the development of green building. In the early development of green building, it's difficult for construction enterprises and consumers to take the initiative to bear incremental costs, so the healthy and sustainable development of green building needs government's policy guidance and regulation.
It can be seen that the development of green building is consistent to government's interest demand. In the process of promoting green building, the government needs to do a lot of work. The development of green building in our country is in the initial stage, in which there have not been complete market incentive mechanism and punishment mechanism, and there are still many imperfect systems and the supervision is not in place in the green building market. The one-sidedness of government performance examination has led to the current development situation of preferring economy to environment, preferring quantity to quality. In some areas, environmental pollution and ecological damage are serious. There is still much work to be done for government on the road to green development.

\section{GAME STUDY AMONG THE ENTITIES OF THE GREEN BUILDING MARKET}

The external effect of green building leads to failure of the production market and consumer market. Enterprises' expansion of the green building market development is not conducive to their own pursuit of more benefits. Under insufficient green consciousness and effective incentive, consumers' increase in green consumption is not conducive to maximizing their utility. The market fails, and the market supply and demand can not be achieved through the price adjustment, thus only the participation of government can solve the problem of market failure.

In China's green building market, construction enterprises, consumers and government all resist and cooperate with each other, and the three entities are in the unity of opposite. Through the market interest game, they can make decisions in favor of themselves. The following is the game behavior analysis of the three entities in green building market. Through the game analysis, we can explore the specific reasons for development dilemma of the green building market.

\section{A. Basic Assumption of the Model}

1) The market entity participating in the game is rational economic people, and all parties are seeking to obtain the maximum benefit output with minimum cost of input;

2) The market information is completely open

3) The game of construction enterprises and consumers is static game

\section{4) The market behavior is voluntary}

\section{B. Game between the Enterprise and Consumer}

Suppose there is only construction enterprise and the consumer in green building market, and the sale behavior is voluntary. The ID utility obtained by consumers in purchase of green building is $\mathrm{V}$, and the cost is $\mathrm{P}$, so the total utility $\mathrm{U}=\mathrm{V}-\mathrm{P}$; consumers can choose to buy traditional buildings or green buildings, and can also choose to give up the purchase and retain the money when they have not found a satisfactory product. Suppose the utility obtained by consumers in purchase is larger than that of the retained money. The earning obtained by construction enterprises in the green building production and sales is $\mathrm{R}$, and the cost is $\mathrm{C}$, so the profit is R-C. 
Production of traditional products will cause a certain pollution, and the fine after being found after is $\mathrm{CP}$, and the probability for pollution to be found is $\alpha$.

The game model is as follows "Table I":

TABLE I. INTEREST GAME MODEL BETWEEN THE GREEN BUILDING ENTERPRISE AND CONSUMER

\begin{tabular}{|c|c|l|c|}
\hline \multicolumn{2}{|c|}{} & \multicolumn{2}{|c|}{ Enterprise } \\
\cline { 3 - 4 } \multicolumn{1}{|c|}{} & $\begin{array}{c}\text { Produce of } \\
\text { green } \\
\text { buildings }\end{array}$ & Produce traditional buildings \\
\hline Consumers & $\begin{array}{c}\text { Buygreen } \\
\text { buildings }\end{array}$ & $\mathrm{Vg}-\mathrm{Pg}, \mathrm{R}-\mathrm{C}$ & $\mathrm{U} 0,-\mathrm{Ct}-\alpha \mathrm{CP}$ \\
\cline { 2 - 4 } & $\begin{array}{c}\text { Buy } \\
\text { traditional } \\
\text { buildings }\end{array}$ & $\mathrm{U} 0,-\mathrm{Cg}$ & $\mathrm{Vt}-\mathrm{Pt}$, , Rt-Ct- $\alpha \mathrm{Cp}$ \\
\hline
\end{tabular}

For the game model conclusion, it can be seen through the analysis of the game model that when the consumers simply pursue for utility maximization, and the enterprises simply pursue for profit maximization, if there is no external intervention, it's difficult to achieve Pareto Optimality in green building market, and there are two possibilities to achieve Pareto Optimality.

\section{WAYS TO PROMOTE THE DEVELOPMENT OF GREEN BUILDING MARKET}

Under China's existing development of productive force and economic system, there following ways for green building's scale development:

\section{A. Reduce the Total Incremental Cost of Green Building} through Green Technology Development and Cost Control inside the Industry

Enhance input in special research funds such as the key green technology and green building material, encourage the promotion and application of green technology. At the technical level, we mainly rely on the relevant consulting service organizations and expert teams; formulate and implement standardized documents such as relevant standards and regulations to standardize the professional development of green building.

\section{B. The Government Should Increase Investment}

The incentive mechanism includes two aspects of capital incentive and policy incentive. For the capital incentives, the government gives capital incentives with different amounts to the construction enterprises based on different levels of green construction projects. The government subsidizes residents who purchase finished houses. For the policy incentives

The government sets up innovation awards for green building, including engineering and technology awards to reward those who meet the national and provincial green building standards; and public building and residential construction projects with significant comprehensive effect in aspects of protection of natural resources and ecological environment, saving energy, materials, water and land, reducing environmental pollution and intelligent system. So as to encourage the construction enterprises, architectural design departments and R\&D institutions to participate in green building innovation and development more.

Take Jiangsu Province as an example, the following measures are taken: (1) Green buildings are rewarded according to the star rating. Reward of 15 yuan, 25 yuan, 35 yuan per square meter is respectively given to designs with one, two, three star label. And designs with operational label will be rewarded 10 yuan more per square meter. The project can apply for capital incentive if it gets the green building evaluation design label or operational label, is put on record in the provincial green label office, gets completed and accepted after 2012, and gets the building energy-efficiency evaluation label. Up to 2014, 42 green construction projects had got 54.27 million yuan of subsidy funds.

(2) Regional demonstration, subsidize according to the area implementing the green building. Subsidy not less than 10 million yuan is given to demonstration area of building energy efficiency and green building; fixed subsidy is given to green building demonstration city (county, district), in which the provincial cities are given 50 million yuan, and counties and districts are given 25 million yuan of subsidy.

(3) The application of renewable energy in construction is subsidized according to the project area or mount of energy saving. Subsidy of about 23 yuan per square is given according to the energy efficiency of the first 3 years of the project.

(4) The energy-saving transformation of the existing buildings is subsidized according to the content of transformation. The energy-saving transformation of the external doors and windows, external shading, roof and exterior insulation is given 15 yuan / square meters for subsidy, and the total subsidy is 45 yuan / square meter. Enterprises offset the incremental cost of green building through the government's capital incentive, and can also make a certain income.

\section{Guide Consumers to Increase Consumption of Green Building with High Cost Performance}

Green building will incur some incremental costs, but for Jiangsu Province with strong construction industry, since the local construction standard has a relatively high starting point, and green building technologies such as building energy efficiency, solar water heating system, rainwater collection system and finished housing have been been generally applied as the basic requirements in the whole province, the incremental cost will be lower than the national average. The specific values are as follows "Table II":

TABLE II. THE INCREMENTAL COST OF GREEN BUILDING IN JIANGSU (UNIT: YUAN / SQUARE METER)

\begin{tabular}{c|c|c|c}
\hline & One-star & Two-star & Three-star \\
\hline Residence & $15 \sim 25$ & $75 \sim 105$ & $125 \sim 15$ \\
\hline Public building & $15 \sim 30$ & $85 \sim 115$ & $210 \sim 285$ \\
\hline
\end{tabular}

Take residence as an example, compared to the current market price of commercial housing, the incremental cost of 
green building accounts for less than $1 \%$ of the unit price of housing, and the green building can significantly reduce the use cost in later period, the life-cycle cost accounting is lower than ordinary buildings' cost, thus from the aspect of comprehensive ecological benefits and living comfort level, the high cost performance of green buildings is more attractive to consumers. Thus it can be seen that the development of green building is necessary for no matter the government's macro development, the enterprises' sustainable development, and the improvement of residents' housing quality.

\section{Formulate and Implement of Standardized Documents}

Such as Relevant Standards and Regulations, Standardize the Professional Development of Green Building

Clearly stipulate the star level requirement for new single buildings, green building requirement for the regional scope, and green operational requirement for existing buildings. Standardize the ten basic systems of government guidance, target assessment, recognition and reward, preparation planning, energy saving verification, demolition record, evaluation label, evaluation promotion, evaluation supervision and administrative punishment.

\section{CONCLUSION}

The promotion of green building has a long way to go with heavy responsibilities, and the government, construction enterprises and consumers face the contradictions of their own interest maximization as the three participant entities. As the inevitable demand of sustainable development, the green building is the development trend of the construction industry. In the green building market, it needs to jointly coordinate the policy level, the construction industry level and the consumption level to harmonize the interests of all the three parties, so as to make our green building market develop healthily and stably.

\section{REFERENCES}

[1] Zhang Wei, The factors affecting the promotion of green building empirical research from the construction industry, Construction Economics, 2008 (2)

[2] Chen Huaming, Discussion on the overview and current situation of green building development, Chinese Houses, 2014 (2)

[3] Pan Huiping, Discussion on the current situation and prospects of the development of green building, Science and Technology Information, 2015 (5)

[4] Li Dongping, The current situation China's green building development and the corresponding detection technology, Building Energy Efficiency, 2015 (3)

[5] Yang Jie, Study on attribution of promoting liability of green building based on institutional mechanism, Journal of Engineering Management, 2014 (12)

[6] Gong Runting, Ren Pengyu, Cai Weiguang, Development direction and suggestion of green building based on consumers' perspective _ Taking Chongqing Municipality as an example, Construction Economics, 2015

[7] Huang Li, Progress Review of Study on Green Building Operation Management, Construction Economics, 2015 (11) 